\title{
Model Standardisasi Pengiriman Kemasan Rantai Dingin pada Usaha Kecil dan Menengah dengan Moda Transportasi Laut
}

\author{
Siti Dwi Lazuardi, Tri Achmadi, Pratiwi Wuryaningrum, Salsabil Nabilah Putri \\ Departemen Teknik Transportasi Laut, Fakultas Teknologi Kelautan, Institut Teknologi Sepuluh Nopember, \\ Jl. Arief Rahman Hakim, Sukolilo, Surabaya, 60111, Indonesia \\ dwilaz@seatrans.its.ac.id
}

\begin{abstract}
Abstrak
Usaha Kecil dan Menengah (UKM) berkontribusi pada Produk Domestik Bruto Indonesia yang meningkat dari 57,84\% menjadi 60,34\% pada tahun 2018. UKM memiliki peran sebesar $20 \%$ pada kegiatan ekspor, khususnya untuk olahan ikan beku. Belum adanya standar kemasan rantai dingin untuk produk ekspor menjadi kendala dalam proses pengiriman. Oleh karena itu, tujuan dari penelitian ini adalah membuat model standardisasi kemasan rantai dingin untuk pengiriman produk ekspor UKM dengan moda transportasi laut. Metode yang digunakan adalah perhitungan biaya logistik untuk memperoleh minimum unit biaya logistik dengan 4 (empat) skenario pemilihan kemasan rantai dingin berstandar. Hasil analisis menunjukkan bahwa skenario 2 yaitu penggunaan kemasan saat ini dengan inovasi kemasan sekunder 1 dapat menghasilkan minimum unit biaya logistik sebesar Rp. 21,44 juta/ton. Sedangkan hasil analisis yang diperoleh menurut waktu adalah skenario 4 dengan penggunaan inovasi kemasan sekunder 2 dengan total waktu 21,45 hari.
\end{abstract}

Kata kunci: biaya logistik, inovasi kemasan ekspor, manajemen rantai dingin, transportasi laut.

\section{Pendahuluan}

Usaha Kecil dan Menengah (UKM) dalam segala sektor membawa kontribusi dalam perekonomian Indonesia, khususnya pada aktivitas ekspor, yaitu peningkatan Produk Domestik Bruto (PDB) dari 57,84\% menjadi 60,34\% di tahun 2018. Salah satu hasil Usaha Kecil dan Menengah (UKM) yang sangat terbuka luas untuk dikembangkan adalah bidang kelautan dan perikanan dengan skala usaha Usaha Kecil dan Menengah (UKM) sebanyak 60.855 unit atau 98,8\% sehingga hasil perikanan oleh UKM berkontribusi besar dalam kegiatan domestik maupun ekspor. Hasil sektor perikanan itu sendiri berkontribusi pada PDB sebesar Rp. 59,98 triliun (Kementerian Kelautan dan Perikanan, 2019).

Hasil perikanan yang dihasilkan oleh para pelaku UKM berada pada sektor budidaya, perikanan tangkap maupun pengolahan. Dalam kegiatan ekspor, hasil perikanan meliputi ikan segar, pembekuan, pengeringan atau penggaraman, pemindangan, pengasapan, pengalengan, tepung ikan, pengawetan, peragian dan lain-lain. Hasil perikanan tersebut dapat berupa bahan makanan yang mempunyai sifat mudah rusak, sehingga membutuhkan penanganan khusus saat pengiriman.

Para pelaku UKM dengan penghasil terbanyak melalui olahan perikanan terutama dalam bentuk ikan beku adalah di daerah Lamongan Jawa Timur. Namun, para pelaku tersebut memiliki kendala dalam melakukan kegiatan ekspor melalui jalur laut. Kendala tersebut terjadi karena tidak adanya standardisasi dalam pengiriman kemasan rantai dingin dengan moda transportasi laut. Hasil perikanan yang dihasilkan oleh UKM tergolong dalam jumlah yang sedikit karena keterbatasan bahan baku sehingga para pelaku usaha cenderung mengirimkan muatan ekspor dengan sistem LCL (Less Than Container Load). Akibatnya, muatan mengalami kerusakan karena proses penanganan dan pengiriman muatan dianggap memiliki karateristik, jenis dan berat yang sama. Selain itu sistem informasi pada pengiriman oleh UKM sangat kurang. Kemasan rantai dingin yang digunakan untuk ekspor saat ini juga sangat sederhana sehingga belum optimal dalam menjamin kualitas produk saat proses perpindahan dan pengiriman muatan. 
Beberapa negara tujuan ekspor hasil perikanan UKM menerapkan standar pengiriman kemasan rantai dingin dalam hal tingkat higienitas dan tingkat kerusakan kemasan saat dikirimkan dengan moda transportasi laut dalam waktu yang lama. Oleh karena itu dibutuhkan model standardisasi pengiriman kemasan rantai dingin untuk produk ekspor UKM dengan menggunakan moda transportasi laut. Standardisasi yang dihasilkan berupa desain kemasan dengan beberapa faktor pengiriman dengan menggunakan moda transportasi laut. Selain itu, standardisasi kemasan ini juga dapat dijadikan acuan untuk pengiriman muatan beku lainnya yang memiliki berat berbeda-beda dengan menggunakan alat angkut lainnya dalam sektor transportasi laut. Adapun tujuan utama dari penelitian ini adalah mengetahui kondisi saat ini ekspor hasil olahan ikan beku dari UKM dengan menggunakan moda transportasi laut, mengetahui model standardisasi pengiriman kemasan rantai dingin untuk produk ekspor UKM dan mengetahui besarnya unit biaya logistik minimum setelah adanya standardisasi kemasan rantai dingin untuk produk ekspor UKM dengan menggunakan moda transportasi laut.

\section{Kajian Literatur}

\section{a. Usaha Kecil dan Menengah (UKM)}

Berdasarkan pada UU No 20 tahun 2008, Usaha Mikro Kecil dan Menengah (UMKM) adalah usaha produktif yang dapat dimiliki oleh perorangan maupun badan usaha yang telah memenuhi kriteria sebagai usaha mikro. Sedangkan Usaha Kecil Menengah (UKM) merupakan suatu usaha ekonomi produktif yang independent dan dapat dilakukan oleh perorangan maupun badan usaha yang bukan merupakan anak perusahaan yang dimiliki, dikuasai atau menjadi bagian baik langsung maupun tidak langsung dari usaha menengh atau usaha besar yang memenuhi kriteria usaha kecil (Tambunan, 2009).

Hasil dari UKM di Indonesia antara lain perdagangan besar dan eceran, penyediaan akomodasi dan penyediaan makan dan minum, dan industri pengolahan. Namun komoditas yang melakukan kegiatan ekspor hasil dari UKM hanya industri pengolahan saja. Industri pengolahan meliputi berbagai kegiatan produksi yang mengubah bentuk bahan baku atau mentah menjadi barang setengah jadi dan barang jadi yang siap digunakan dan dikonsumsi. Dalam pengiriman muatan, terdapat dua sistem yang digunakan dalam pengiriman barang ekspor diantaranya yaitu Full Container Load (FCL) atau pengiriman barang dengan menggunakan kontainer dimana pengiriman barang dalam satu kontainer penuh hanya dimiliki oleh satu pengirim dan tidak bercampur dengan barang milik orang lain dan Less Than Container Load (LCL) atau pengiriman barang dengan menggunakan kontainer dimana pengiriman barang dalam satu kontainer penuh terdiri dari beberapa pengirim yang digabungkan dalam kontainer tersebut (Suyono, 2010).

\section{b. Biaya Logistik}

Logistik mempunyai peranan penting dalam mengatur hubungan antara supplier/pemasok sampai dengan konsumen. Produk yang telah diproduksi dan didistribusikan kepada para konsumen sebisa mungkin mampu menekan ongkos serendah mungkin. (Christopher, 1998). Dalam proses logistik dan distribusi terdapat beberapa komponen sebagai berikut:

1) Biaya Produksi (Production Costs): Biaya akibat dari pembuatan produk;

2) Biaya Pengepakan (Packaging Costs): Biaya yang muncul akibat pengemasan;

3) Biaya Sistem Informasi (Information System Costs): Biaya untuk pengumpulan informasi;

4) Biaya Transportasi (Transport Cost): Biaya memindahkan barang dari asal - tujuan. Biaya ini bergantung dengan jumlah dan lokasi tujuan, pusat distribusi, dan barang yang dikirimkan;

5) Biaya penjualan yang hilang (Lost Sale Cost): Biaya dari keuntungan yang hilang akibat pesanan yang tidak dapat dipenuhi;

6) Biaya Persediaan (Inventory Cost): Biaya untuk kegiatan penyusunan sistem persediaan barang yang optimal;

7) Biaya Konsolidasi (Consolidation Cost): Biaya untuk menyatukan muatan dalam 1 (satu) petikemas; 
8) Biaya Pergudangan (Warehousing Cost): Biaya penyimpanan barang di gudang, dipengaruhi tipe penyimpanan dan penanganan barang yang digunakan, jumlah dan volume barang yang disimpan serta ukuran dan lokasi gudang itu sendiri (Rushton, 2010).

\section{c. Cold Chain Management}

Cold chain management atau manajemen rantai dingin adalah bagian dari manajemen rantai pasok yang bertujuan untuk menjaga suhu suatu produk agar tetap terjaga selama proses pengumpulan, pengolahan, dan distribusi komoditas hingga ke tangan konsumen (Simatupang, 2016). Logistik rantai dingin sendiri merupakan gabungan antara kegiatan logistik dan pengendalian suhu. Dalam logistik rantai dingin, cold storage sangat penting sebagai alat pembeku dan tempat penyimpanan ikan. Menurut Sondoro (2016), dalam rangka mendapatkan sebuah sistem rantai dingin yang tepat, terdapat 4 (empat) tahap kritis yang harus dicermati dalam sistem rantai pendingin produk beku, yaitu: (1) penanganan saat diproses awal, (2) penyimpanan dan pengolahan saat tiba di darat, (3) penanganan saat transportasi di darat ataupun di laut ke lokasi tujuan dan (4) penanganan saat bongkar muat dan sistem distribusi ke konsumen (Sondoro, 2016).

Pengendalian suhu dalam logistik rantai dingin sangat penting karena barang yang dikirim memiliki karateristik khusus sehingga harus selalu ada dalam keadaan suhu rendah Pengendalian suhu ini menjaga agar barang yang dikirim tetap dalam keadaan baik sampai ditujuan. Infrastruktur pendukung logistik rantai dingin sendiri terdapat lima faktor yaitu pengadaan pasokan, moda transportasi awal, gudang penyimpanan, moda transportasi lanjutan dan pelanggan akhir (Bianca, 2016).

\section{d. Standardisasi}

Menurut UU No. 102 tahun 2000 tentang Standardisasi Nasional, menyatakan bahwa pengertian dari standardisasi adalah spesifikasi teknis atau sesuatu yang dibakukan termasuk tata cara dan metode yang disusun berdasarkan keputusan semua pihak yang terkait dengan memperhatikan syarat - syarat keselamatan, keamanan, kesehatan, lingkungan hidup, perkembangan ilmu pengetahuan dan tekbologi, perkembangan masa kini dan masa yang akan datang untuk memperoleh manfaat sebesar - besarnya.

Banyak negara tujuan ekspor menuntut persyaratan standar untuk pengiriman produk beku. Hal itu terbukti dengan beberapa kasus penolakan barang dari Indonesia ke luar negeri karena produk yang djual tidak memenuhi persyaratan standar negara tujuan (Arduiona, 2010).

1) Standar Ekspor Ikan Beku

Ikan beku adalah produk ikan yang sudah melewati proses pembekuan yang cukup untuk mereduksi suhu seluruh produk sampai pada suatu tingkat suhu yang cukup rendah. Pembekuan ikan ini dilakukan untuk mempertahankan selama pengangkutan, penyimpanan dan distribusi. Secara internasional, persyaratan produk ekspor ikan beku harus memenuhi persyaratan WHO dan FAO yang dituangkan dalam Code Practice for Fish and Fishery Product. Adapun hal yang harus diperhatikan untuk kargo yang mudah rusak selama transportasi adalah: suhu, kandungan air, sirkulasi dan distribusi udara, desain kemasan, kualitas enyimpanan, gudang berpendingin, alat bongkar muat, tranportasi berventilasi (Codex Alimentarius Commission, 2009).

2) Standar Kemasan Rantai Dingin

Kemasan rantai dingin memiliki persyaratan tinggi dalam penyimpanan dan pengiriman muatan. Dalam perencanaan dan desain kemasan rantai dingin, dimensi teknik dari semua fasilitas rantai dingin secara langsung berkaitan dengan ukuran karena non-standardisasi. Fasilitas langsung mempengaruhi pembentukan, desain dan optimalisasi solusi sistem penyimpanan, efesiensi operasi peralatan penanganan muatan, pengiriman muatan dan layanan operasi rantai dingin. Oleh karena itu, realisasi unit dan standardisasi kemasan rantai dingin dapat mengurangi total biaya sistem logistik dan memperoleh manfaat ekonomi terbaik dengan alokasi sumber daya yang optimal, dan sistem kemasan rantai dingin dapat memberikan layanan yang memuaskan bagi konsumen (Simatupang, 2016). 


\section{e. Inovasi Kemasan dalam Pengiriman Jalur laut}

Beberapa penelitian sebelumnya menunjukan adanya pengaruh model kemasan yang digunakan dalam pengiriman muatan dengan moda transportasi laut. Dalam penelitian Izza (2017) berfokus pada kemasan yang digunakan pada pelayaran rakyat Kalimas Surabaya dengan rute domestik. Armada yang digunakan adalah kapal pelayaran rakyat dengan proses penataan muatan berada langsung pada kapal, dan muatan yang digunakan adalah muatan kargo (Izza, 2017). Selain itu, Johar (2019) juga membuat inovasi kemasan yang dapat digunakan pada angkutan laut wilayah kepulauan dalam rute domestik. Armada yang digunakan pada penelitian ini adalah kapal petikemas dan kapal perintis dengan proses penataan muatan berada pada truk dan petikemas dengan ukuran standar, dan muatan yang digunakan adalah muatan kargo (Johar, 2019).

\section{Metode Penelitian}

\section{b. Biaya Logistik}

Dengan menggunakan pendekatan perhitungan biaya logistik berdasarkan (Rushton, 2010) dan (Zaroni, 2017), maka diperoleh formula sebagai berikut:

$$
T C=M C+S C_{1}+S C_{2}+P C+T C_{1}+T C_{2}+D C
$$

Keterangan:

$$
\begin{aligned}
& T C=\text { Total Costs }(\mathrm{Rp} .) \\
& M C=\text { Material Costs }(\mathrm{Rp} .) \\
& S C_{1}=\text { Storage Costs }(\mathrm{Rp} .) \\
& S C_{2}=\text { Consolidation Costs }(\mathrm{Rp} .) \\
& P C=\text { Packaging Costs }(\mathrm{Rp} .) \\
& T C_{1}=\text { Land Transportation Costs (Rp.) } \\
& T C_{2}=\text { Sea Transportation Costs (Rp.) } \\
& D C=\text { Dunnage Costs (Rp.) }
\end{aligned}
$$

Sedangkan untuk menghitung total waktu yang dibutuhkan dalam pengiriman produk ekspor UKM dengan moda transportasi laut menggunakan formula sebagai berikut:

$$
T T=D T+S T+L T
$$

Keterangan:

$$
\begin{aligned}
& T T=\text { Total Time (hari) } \\
& D T=\text { Delivery Time (hari) } \\
& S T=\text { Storage Time (hari) } \\
& L T=\text { Loading Time (hari) }
\end{aligned}
$$

\section{c. Load factor (LF)}

Besaran load factor menggambarkan proporsi dari kapasitas terpakai terhadap kapasitas yang tersedia. Artinya, jika load factor $100 \%$ menunjukkan seluruh kapasitas terisi (tidak ada ruang kosong). Dalam penelitian ini perhitungan load factor dibagi berdasarkan berat dan volume dari kemasan.

$$
\begin{aligned}
& \text { Load Factor }(\%)=\frac{\text { Kapasitas Terpakai }}{\text { Kapasitas Terpasang }} \times 100 \% \\
& L F \text { Berat }=\frac{C_{1} \cdot(x+W k)}{C o_{1}} \times 100 \% \\
& L F \text { Volume }=\frac{C_{2} \cdot V k}{C o_{2}} \times 100 \% \\
& \text { Broken Stowage }(\%)=100 \%-L F \text { Volume }(\%) \\
& \text { Loss Revenue Berat }(\%)=100 \%-\text { LF Berat } \%
\end{aligned}
$$




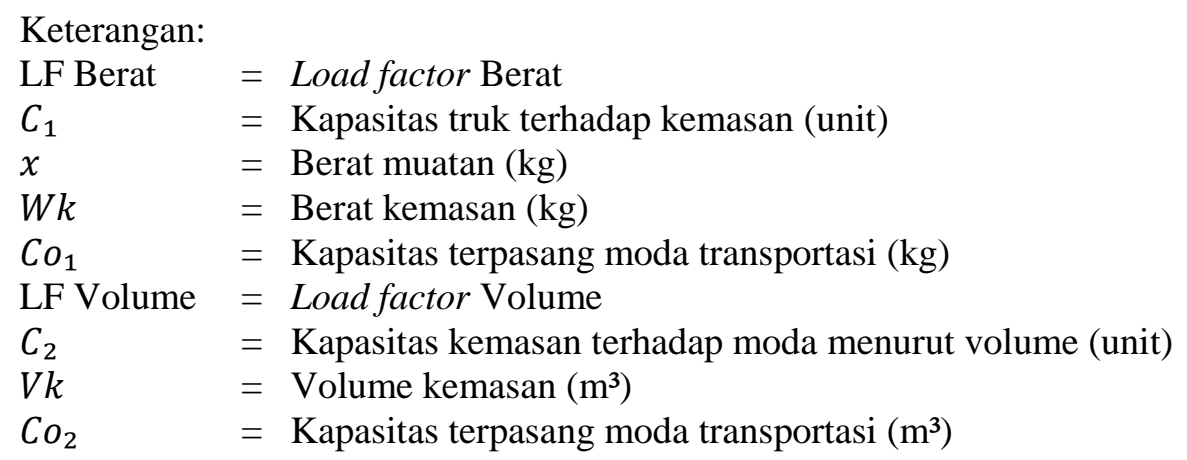

\section{d. Analisis Kekuatan/ Buckling}

Analisis kekuatan/ buckling adalah suatu proses dimana suatu stuktur tidak mampu mempertahankan bentuk aslinya. Buckling atau tegangan tekuk ini biasanya terjadi akibat kelebihan beban. Berikut formula yang digunakan dalam analisis kekuatan kemasan:

Keterangan:

$$
\operatorname{Pcr}=\frac{\pi^{2} \cdot E \cdot I}{(K \cdot L)^{2}}
$$

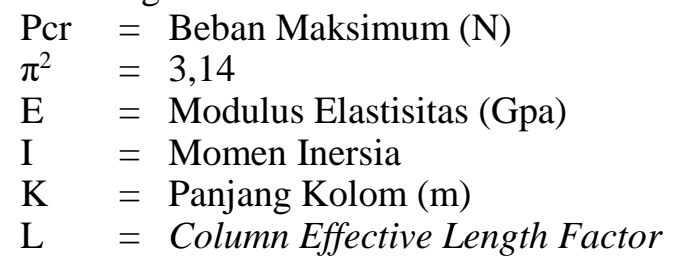

\section{Hasil dan Pembahasan}

\section{a. Permintaan Ekspor Ikan Beku}

Menurut International Trade Center, diketahui jumlah (\%) menurut hasil olahan ikan di negara tujuan ekspor. Dari beberapa produk olahan ikan terlihat bahwa produk ikan beku memiliki nilai tertinggi dalam kegiatan ekspor ke China dan Jepang sebesar 46,7\% dan 42,6\% (International Trade Center, 2018). Hubungan perdagangan Indonesia dengan China dan Jepang adalah salah satu hubungan yang sangat penting bagi Indonesia dan negara tersebut. Hubungan ekspor antara Indonesia dengan China dan Jepang berada pada sektor perikanan yang cukup tinggi yaitu berada pada produk olahan ikan beku. Hubungan ekspor impor antara Indonesia dengan China dan Jepang lebih terlihat lagi ketika 2 (dua) negara tersebut juga mengekspor olahan perikanan ke negara Indonesia.

Kontribusi Usaha Kecil dan Menengah (UKM) terhadap kegiatan ekspor cukup tinggi yaitu 20\% dari jumlah keseluruhan ekspor hasil olahan ikan ke beberapa negara. Beberapa UKM pada studi kasus penelitian ini yaitu daerah Lamongan, Jawa Timur mampu mengekspor muatan sebesar 150 ton/trip untuk 2 (dua) negara tujuan yaitu China dan Jepang dengan 5 (lima) macam muatan yang berbeda beda yaitu ikan layang beku, baby gurita beku, ikan swanggi beku, ikan kapasan beku, dan udang beku (Badan Pusat Statistik, 2017).

\section{b. Analisis Kondisi Saat Ini}

Usaha Kecil dan Menengah (UKM) sebagai pelaku ekspor olahan ikan beku mengirimkan muatan dengan sistem Less than Container Load (LCL). Pengiriman ekspor ke negara tujuan ini dilakukan dengan menggukanan moda transportasi laut yaitu kapal petikemas. Dengan dipilihnya sistem Less than Container Load (LCL) menunjukan bahwa moda transportasi yang digunakan untuk pengiriman muatan tersebut seperti truk cdd reefer dan reefer container $40 \mathrm{ft}$ berisi beberapa jenis muatan dengan berat tiap muatan dan kemasan, karateristik kemasan dan dimensi kemasan yang berbeda-beda. 
Tabel 1. Dimensi Kemasan Ekspor Saat Ini

\begin{tabular}{|c|c|c|c|c|c|c|c|}
\hline \multirow{2}{*}{ Muatan } & \multicolumn{3}{|c|}{ Dimensi } & \multirow{2}{*}{$\begin{array}{c}\text { Volume } \\
\text { (m3) }\end{array}$} & \multirow{2}{*}{$\begin{array}{c}\text { Berat Muatan } \\
(\mathrm{kg})\end{array}$} & \multirow{2}{*}{$\begin{array}{c}\text { Berat Kemasan } \\
(\mathrm{kg})\end{array}$} & \multirow{2}{*}{$\begin{array}{l}\text { Total Berat } \\
\text { (kg) }\end{array}$} \\
\hline & $\mathbf{P}(\mathbf{m})$ & $\mathbf{L}(\mathbf{m})$ & $\mathbf{T}(\mathbf{m})$ & & & & \\
\hline Ikan layang & 0,41 & 0,33 & 0,14 & 0,0189 & 10 & 0,1 & 10,1 \\
\hline Baby gurita & 0,41 & 0,33 & 0,14 & 0,0189 & 10 & 0,1 & 10,1 \\
\hline Ikan kapasan & 0,39 & 0,31 & 0,13 & 0,0157 & 10 & 0,1 & 10,1 \\
\hline Ikan Swanggi & 0,41 & 0,33 & 0,14 & 0,0183 & 10 & 0,1 & 10,1 \\
\hline Udang & 0,39 & 0,31 & 0,13 & 0,0157 & 10 & 0,1 & 10,1 \\
\hline
\end{tabular}

Analisis yang digunakan dalam memperhitungkan jumlah kemasan muatan olahan ikan beku dalam penanganan dan pengiriman muatan adalah menurut dimensi kemasan terhadap moda transportasi yang digunakan untuk pengiriman muatan dengan mempertimbangkan kapasitas kemasan terhadap volume truk cdd reefer dan reefer container $40 \mathrm{ft}$ dan kapasitas kemasan terhadap berat muatan ditambah berat kemasan terhadap berat truk cdd reefer dan reefer container $40 \mathrm{ft}$. Karena Less than Container Load (LCL), maka jumlah kemasan yang dapat ditampung oleh moda pengangkut berbeda-beda.

Saat ini, para pelaku ekspor muatan tidak memikirkan load factor berat ataupun load factor volume saat mengirimkan muatan dengan menggunakan moda transportasi darat. Sehingga para pelaku tidak jarang kehilangan kesempatan untuk mengirimkan muatan atau bahkan muatan yang dikirim melebihi kapasitas moda transportasi tersebut.

Tabel 2. Kapasitas Kemasan Ekspor Saat Ini terhadap Truk CDD Reefer

\begin{tabular}{ccccccccc}
\hline Skenario & $\begin{array}{c}\text { Berat } \\
\text { (ton) }\end{array}$ & $\begin{array}{c}\text { Volume } \\
(\mathbf{m 3})\end{array}$ & $\begin{array}{c}\text { Kemasan } \\
\text { Primer } \\
\text { (unit) }\end{array}$ & $\begin{array}{c}\text { Kemasan } \\
\text { Sekunder } \\
\text { (unit) }\end{array}$ & $\begin{array}{c}\text { Load } \\
\text { factor } \\
\text { Berat }\end{array}$ & $\begin{array}{c}\text { Load } \\
\text { factor } \\
\text { Volume }\end{array}$ & $\begin{array}{c}\text { Broken } \\
\text { stowage }\end{array}$ & $\begin{array}{c}\text { Jumlah } \\
\text { Moda }\end{array}$ \\
\hline \multirow{3}{*}{ Kemasan } & & 25,12 & & & $112 \%$ & $82 \%$ & $18 \%$ & 2 \\
saat ini & \multirow{2}{*}{152} & 25,12 & & & $112 \%$ & $82 \%$ & $18 \%$ & 2 \\
& & 29,61 & \multirow{2}{*}{15.000} & - & $159 \%$ & $96 \%$ & $4 \%$ & 2 \\
& & 25,64 & & & $118 \%$ & $83 \%$ & $17 \%$ & 2 \\
& 29,27 & & & $157 \%$ & $95 \%$ & $5 \%$ & 2 \\
\hline
\end{tabular}

Tabel 3. Kapasitas Kemasan Ekspor Saat Ini terhadap Reefer Container $40 \mathrm{ft}$

\begin{tabular}{cccccccccc}
\hline Skenario & $\begin{array}{c}\text { Berat } \\
\text { (ton) }\end{array}$ & $\begin{array}{c}\text { Volume } \\
\text { (m3) }\end{array}$ & $\begin{array}{c}\text { Kemasan } \\
\text { Primer } \\
\text { (unit) }\end{array}$ & $\begin{array}{c}\text { Kemasan } \\
\text { Sekunder } \\
\text { (unit) }\end{array}$ & $\begin{array}{c}\text { Load } \\
\text { factor } \\
\text { Berat }\end{array}$ & $\begin{array}{c}\text { Load } \\
\text { factor } \\
\text { Volume }\end{array}$ & $\begin{array}{c}\text { Broken } \\
\text { stowage }\end{array}$ & $\begin{array}{c}\text { Jumlah } \\
\text { Petikemas }\end{array}$ & $\begin{array}{c}\text { Jumlah } \\
\text { Moda }\end{array}$ \\
\hline $\begin{array}{c}\text { Kemasan } \\
\text { saat ini }\end{array}$ & 152 & 43,79 & 15.000 & - & $99 \%$ & $66 \%$ & $34 \%$ & 6 & 6 \\
\hline
\end{tabular}

Perhitungan waktu pada penelitian ini dimulai dari door to port, port to port, port to door. Perhitungan waktu door to port dimulai dari nelayan di Lamongan - Usaha Kecil dan Menengah (UKM) Lamongan - konsolidasi asal Lamongan - pelabuhan asal Surabaya. Selain menghitung waktu pengiriman muatan, terjadi proses penanganan muatan untuk diangkut dengan moda transportasi darat yang digunakan dan waktu proses penyimpanan di cold storage. Perhitungan port to port dimulai dari pelabuhan asal Surabaya - pelabuhan transhipment di Singapore dan dilanjutkan menuju pelabuhan tujuan di China dan Jepang menggunakan moda transportasi laut. Perhitungan pengiriman waktu ini meliputi waktu saat berlayar dan waktu bongkar muat di pelabuhan. Perhitungan waktu pengiriman port to door meliputi pengiriman mulai dari pelabuhan tujuan di China dan Jepang menuju konsolidasi tujuan di masing - masing negara dengan moda transportasi darat.

Perhitungan biaya pada penelitian ini meliputi biaya pengiriman dengan moda transportasi, biaya pengepakan, biaya produksi, biaya pendapatan yang hilang, dan biaya penyimpanan dan konsolidasi. Biaya pengiriman diantaranya door to port, port to port, dan port to door. Biaya pengiriman 
menggunakan moda transportasi darat meliputi biaya trucking berupa biaya sewa truck dan biaya sewa reefer container $40 \mathrm{ft}$. Biaya saat port to port meliputi biaya perjalanan kapal berlayar, tarif pelabuhan berupa tarif jasa pelayanan barang dan kapal, biaya bongkar muat di masing - masing pelabuhan dan biaya penumpukan petikemas di lapangan penumpukan. Selanjutnya biaya pengepakan timbul karena olahan ikan beku dikemas dengan menggunakan kemasan saat ini ataupun inovasi kemasan. Biaya produksi timbul akibat adanya bahan baku yang akan diproduksi sebagai muatan yang akan diekspor ke negara tujuan. Biaya pendapatan yang hilang timbul akibat adanya ruang sisa yang tidak dapat digunakan karena berat yang diangkut sudah mencapai $100 \%$. Biaya penyimpanan dan konsolidasi timbul akibat para UKM menyimpan dan mengkonsolidasikan muatan mereka pada gudang konsolidasi. Penyimpanan dan konsolidasi muatan UKM ini meliputi biaya asuransi, biaya pemeliharaan, administrasi dan pajak.

\section{c. Analisis Perbandingan Kemasan Saat Ini dengan Inovasi Kemasan}

\section{1) Skenario 1}

Skenario 1 pada penggunaan inovasi kemasan primer 1 dengan material bahan Expanded Polystyrene (EPS) Cooler Box dan Corrugated Box. Dimensi penggunaan skenario 1 atau inovasi kemasan primer 1 adalah panjang $0,432 \mathrm{~m}$, lebar $0,352 \mathrm{~m}$, tinggi $0,165 \mathrm{~m}$ sehingga volume sebesar 0,03 $\mathrm{m}^{3}$. Berat muatan tiap kemasan adalah $10 \mathrm{~kg}$ dengan berat kemasan inovasi kemasan primer 1 adalah $0,4 \mathrm{~kg}$. Skenario 1 atau inovasi kemasan primer 1 dapat digunakan 5 kali pemakain dengan suhu $-25^{\circ} \mathrm{C}$.

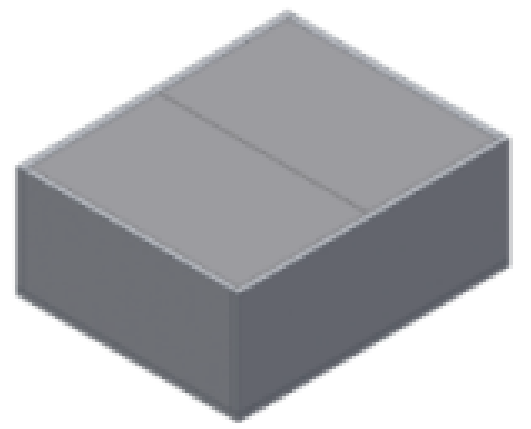

Gambar 1. Skenario 1
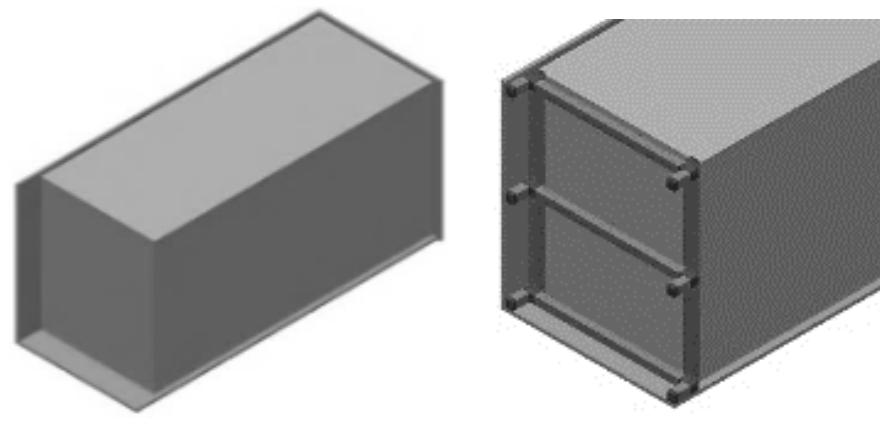

Gambar 2. Penataan Skenario 1 pada Truk CDD Reefer

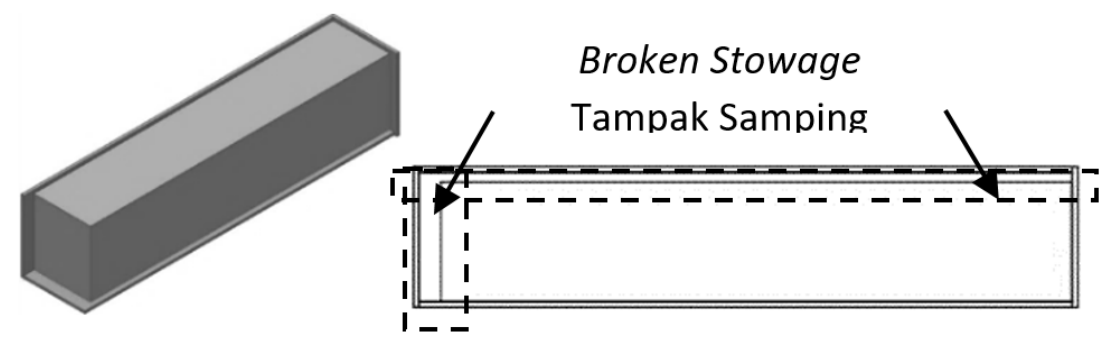

Gambar 3. Penataan Skenario 1 pada Reefer Container $40 \mathrm{ft}$ 
Skema pengiriman muatan dengan penggunaan skenario 1 masih memerlukan jumlah Tenaga Kerja Bongkar Muat (TKBM) dan jumlah alat bongkat muat sama seperti kemasan saat ini. Alat bongkar muat yang digunakan untuk proses penanganan muatan ke dalam truk cdd reefer dan reefer container $40 \mathrm{ft}$ adalah pallet dan handpallet manual.

\section{2) Skenario 2}
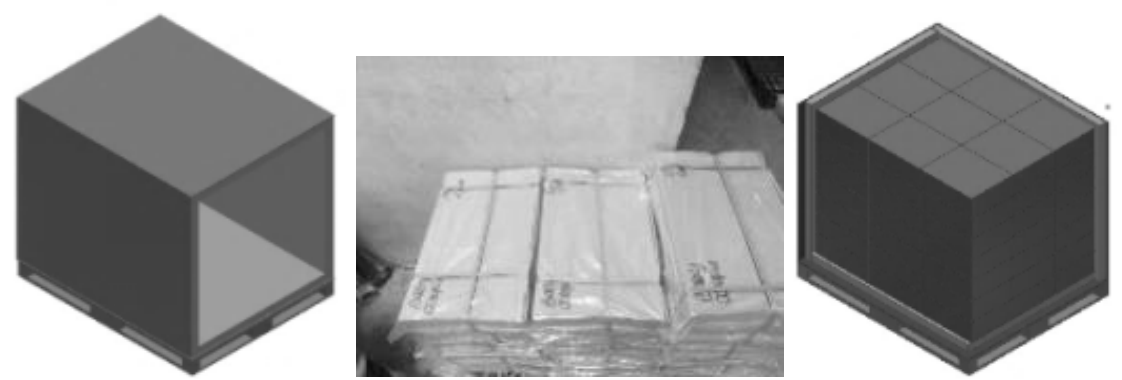

Gambar 4. Skenario

Skenario 2 dalam penelitian ini adalah penggunaan kemasan saat ini dengan inovasi kemasan sekunder 1 dengan moda transportasi darat berupa truk cdd reefer dan moda pengangkut reefer container $40 \mathrm{ft}$. Spesifikasi desain inovasi kemasan sekunder 1 adalah panjang 1,33 m, lebar 1,09 m, tinggi 1,17 $\mathrm{m}$ sehingga total volume adalah 1,68 $\mathrm{m}^{3}$. Berat kemasan inovasi kemasan sekunder 1 adalah 87,6 dengan kapasitas 63 kemasan dengan berat $630 \mathrm{~kg}$ sehingga berat total yang didapat 723,9 kg. Inovasi kemasan sekunder 2 ini dapat tahan 15 kali pemaiakan dengan suhu $-20^{\circ} \mathrm{C}$. Material kemasan yang digunakan adalah Expanded Polypropylene (EPP) Cooler Box dan Low Density Polyethylene (LDPE).
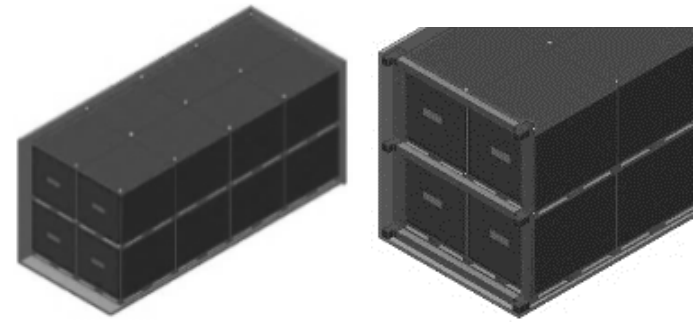

Gambar 5. Penataan Skenario 2 pada Truk CDD Reefer
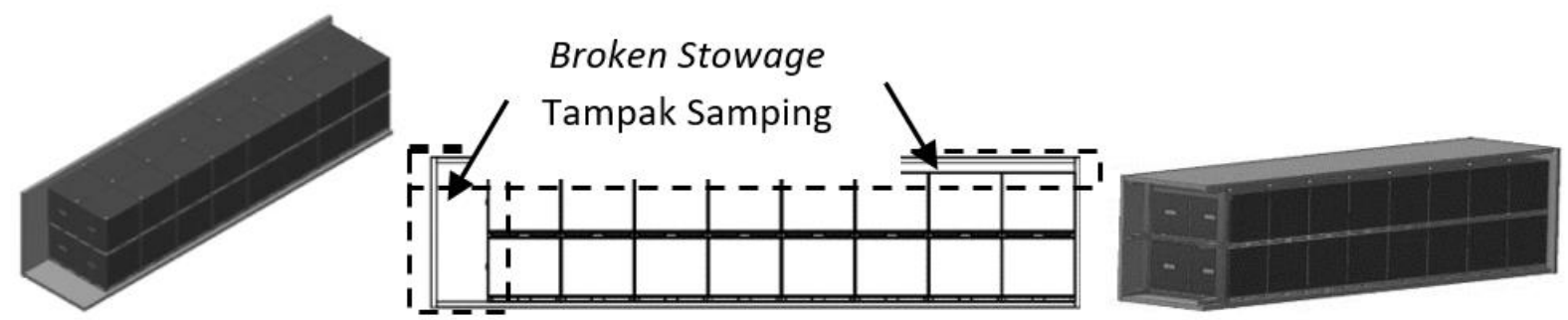

Gambar 6. Penataan Skenario 2 pada Reefer Cotaniner $40 \mathrm{ft}$

Skema pengiriman dengan menggunakan skenario 2 (dua) berbeda dengan penggunaan kemasan saat ini dan skenario 1 karena tidak membutuhkan alat bongkar muat dan jumlah Tenaga Kerja Bongkar Muat (TKBM) sebanyak kemasan sebelumnya. Alat bongkar muat yang dibutuhkan hanya handforklift manual tanpa pallet karena inovasi kemasan sekunder 2 didesain mempunyai kaki kemasan seperti pallet guna mengurangi biaya logistik dan waktu penanganan muatan. 


\section{3) Skenario 3}
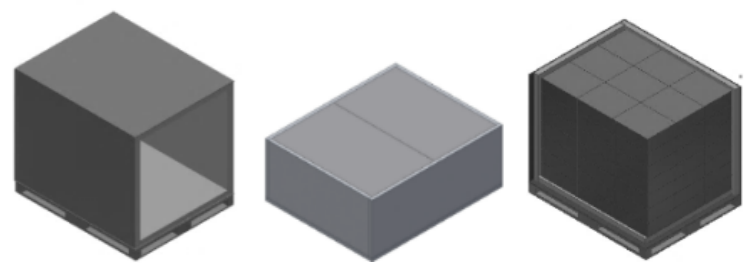

Gambar 7. Skenario 3

Skenario 3 dalam penelitian ini adalah kombinasi inovasi kemasan primer 1 dan inovasi kemasan sekunder 1 dengan moda transportasi darat truk cdd reefer dan moda pengangkut reefer container $40 \mathrm{ft}$.
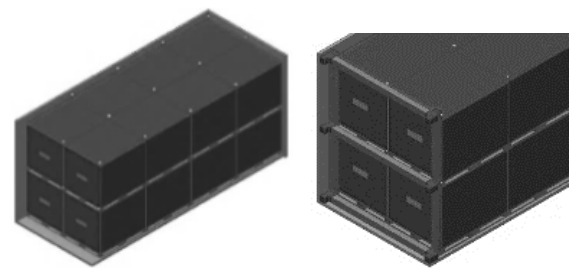

Gambar 8. Penataan Skenario 3 pada Reefer Container $40 \mathrm{ft}$
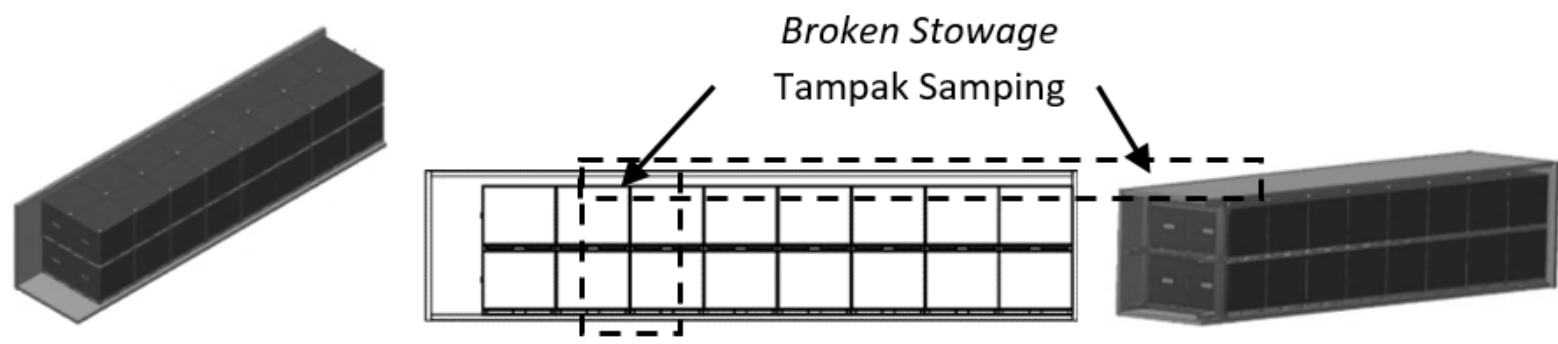

Gambar 9. Penataan Skenario 3 pada Reefer Container $40 \mathrm{ft}$

Skema pengiriman dengan penggunaan skenario 3 sama seperti penggunaan skenario 2 yaitu tidak membutuhkan jumlah alat bongkar muat dan jumlah Tenaga Kerja Bongkar Muat (TKBM) tidak banyak. Alat bongkar muat yang digunakan hanya handpallet manual saja sehingga biaya logistik dan waktu penanganan muatan berkurang.

\section{4) Skenario 4}

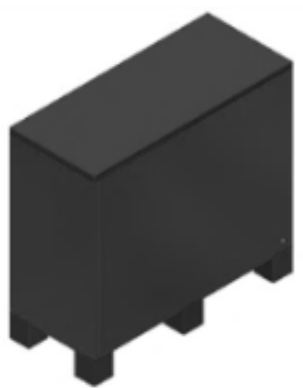

Gambar 10. Skenario 4

Skenario 4 dalam penelitian ini adalah penggunaan inovasi kemasan sekunder 2 dengan moda transportasi darat truk cdd reefer dan moda pengangkut reefer container $40 \mathrm{ft}$. Material yang digunakan inovasi kemasan skenario 4 adalah High Density Polyethylene (HDPE). Spesifikasi desain inovasi kemasan sekunder 2 adalah panjang $0,82 \mathrm{~m}$, lebar $0,35 \mathrm{~m}$, tinggi $0,76 \mathrm{~m}$, dan volume $0,22 \mathrm{~m}^{3}$. Inovasi kemasan ini mampu menampung 10 kemasan dengan total $100 \mathrm{~kg}$. Berat kemasan inovasi ini adalah 39,9 sehingga berat total sebesar 142,4 kg. Inovasi kemasan sekunder 2 mampu bertahan selama $10 \mathrm{kali}$ pemakaian dengan suhu $-20^{\circ} \mathrm{C}$. 


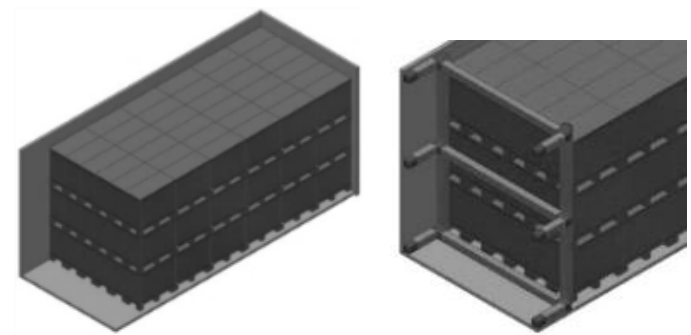

Gambar 11. Penataan Skenario 4 pada Truk CDD Reefer

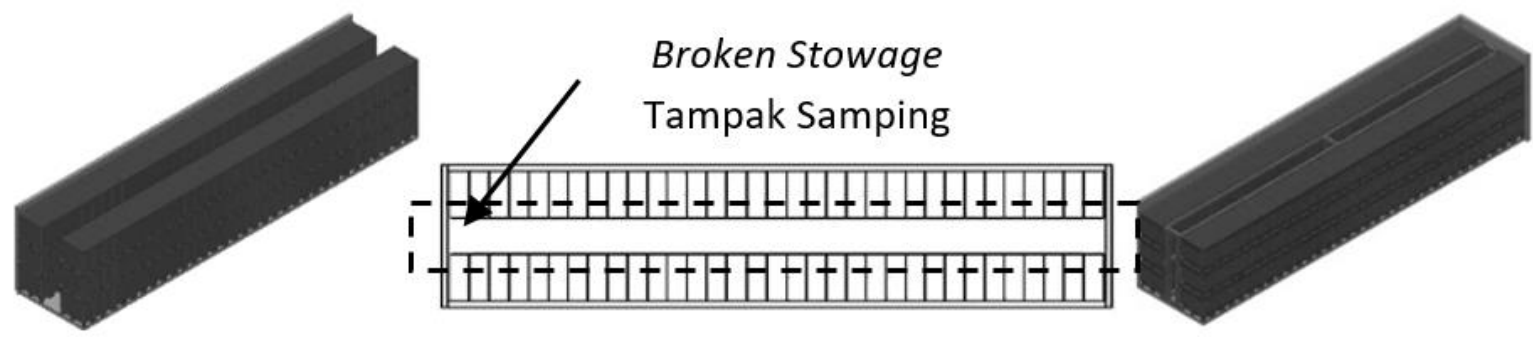

Gambar 12. Penataan Skenario 4 pada Reefer Container $40 \mathrm{ft}$

Skema pengiriman dengan penggunaan skenario 4 pada penelitian juga tidak membutuhkan jumah alat bongkar muat dan jumlah Tenaga Kerja Bongkar Muat (TKBM) sebanyak penggunaan kemasan saat ini dan skenario 1. Inovasi kemasan sekunder ini didesain mempunyai kaki yang dapat digunakan langsung dengan handforkflit manual sehingga dapat mengurangi biaya logistik dan waktu penanganan muatan.

\section{d. Perbandingan Kapasitas Ruang Muat}

Setiap skenario memiliki kapasitas ruang muat pada moda transportasi dan moda pengangkut yang berbeda - beda karena berat dan dimensi volume setiap kemasan berbeda - beda. Berikut perbandingan kapasitas ruang muat untuk truk cdd reefer dan reefer container $40 \mathrm{ft}$ :

Tabel 4. Perbandingan Kapasitas Ruang Muat di Truk CDD Reefer

\begin{tabular}{ccccccccc}
\hline Skenario & $\begin{array}{c}\text { Berat } \\
\text { (ton) }\end{array}$ & $\begin{array}{c}\text { Volume } \\
(\mathbf{m} 3)\end{array}$ & $\begin{array}{c}\text { Kemasan } \\
\text { Primer } \\
\text { (unit) }\end{array}$ & $\begin{array}{c}\text { Kemasan } \\
\text { Sekunder } \\
\text { (unit) }\end{array}$ & $\begin{array}{c}\text { Load } \\
\text { factor } \\
\text { Berat }\end{array}$ & $\begin{array}{c}\text { Load } \\
\text { factor } \\
\text { Volume }\end{array}$ & $\begin{array}{c}\text { Broken } \\
\text { stowage }\end{array}$ & $\begin{array}{c}\text { Jumlah } \\
\text { Moda }\end{array}$ \\
\hline 1 & 156 & 27,10 & 15.000 & - & $93 \%$ & $88 \%$ & $12 \%$ & 13 \\
2 & 172 & 26,84 & 15.000 & 238 & $97 \%$ & $87 \%$ & $13 \%$ & 15 \\
3 & 182 & 26,84 & 15.000 & 238 & $102 \%$ & $87 \%$ & $13 \%$ & 15 \\
4 & 214 & 23,65 & 15.000 & 1.500 & $28 \%$ & $77 \%$ & $23 \%$ & 14 \\
\hline
\end{tabular}

Tabel 5. Perbandingan Kapasitas Ruang Muat di Reefer Container $40 \mathrm{ft}$

\begin{tabular}{cccccccccc}
\hline Skenario & $\begin{array}{c}\text { Berat } \\
\text { (ton) }\end{array}$ & $\begin{array}{c}\text { Volume } \\
(\mathbf{m 3})\end{array}$ & $\begin{array}{c}\text { Kemasan } \\
\text { Primer } \\
\text { (unit) }\end{array}$ & $\begin{array}{c}\text { Kemasan } \\
\text { Sekunder } \\
\text { (unit) }\end{array}$ & $\begin{array}{c}\text { Load } \\
\text { factor } \\
\text { Berat }\end{array}$ & $\begin{array}{c}\text { Load } \\
\text { factor } \\
\text { Volume }\end{array}$ & $\begin{array}{c}\text { Broken } \\
\text { stowage }\end{array}$ & $\begin{array}{c}\text { Jumlah } \\
\text { Petikemas }\end{array}$ & $\begin{array}{c}\text { Jumlah } \\
\text { Moda }\end{array}$ \\
\hline 1 & 156 & 61,75 & 15.000 & - & $100 \%$ & $93 \%$ & $7 \%$ & 6 & 6 \\
2 & 172 & 59,16 & 15.000 & 238 & $100 \%$ & $89 \%$ & $11 \%$ & 7 & 7 \\
3 & 182 & 56,01 & 15.000 & 238 & $100 \%$ & $84 \%$ & $16 \%$ & 7 & 7 \\
4 & 214 & 39,26 & 15.000 & 1.500 & $100 \%$ & $59 \%$ & $41 \%$ & 8 & 8 \\
\hline
\end{tabular}

Perbandingan jumlah kemasan terangkut memiliki kapasitas yang berbeda - beda dari skenario 1 hingga skenario 4. Perbandingan kapasitas ini dapat dilihat dari \% kehilangan kemasan yang tidak dapat diangkut. 


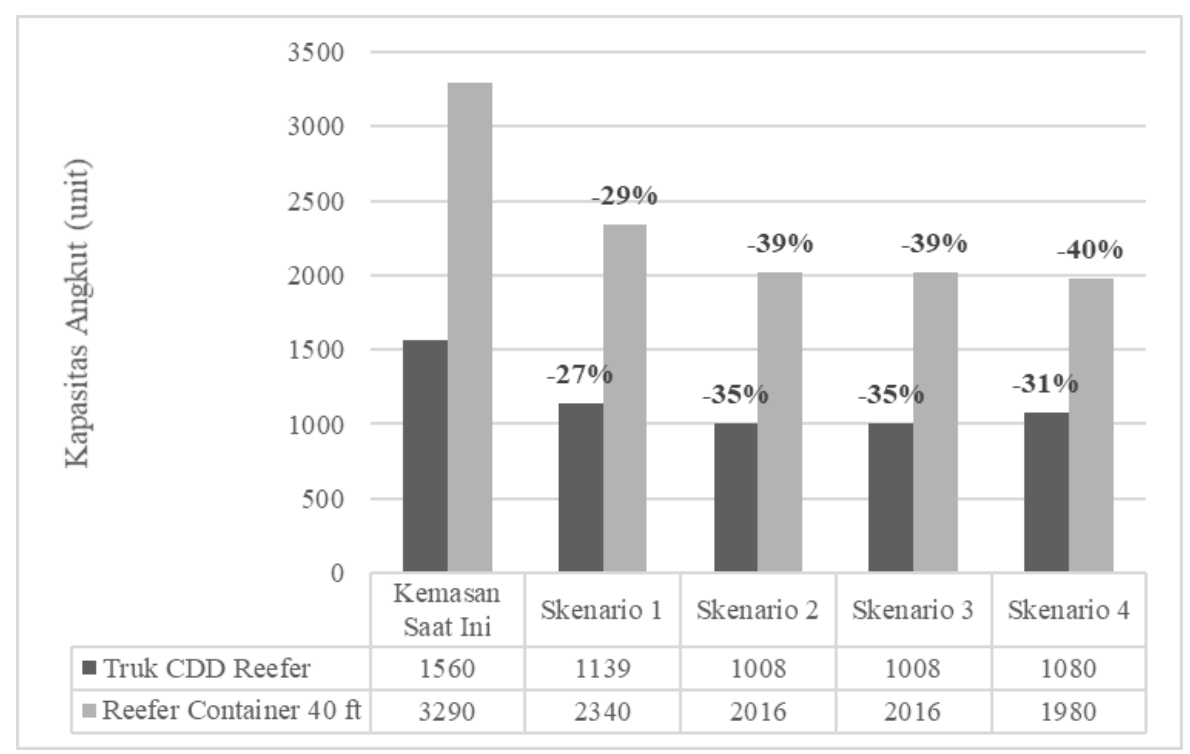

Gambar 13. Perbandingan Jumlah Kemasan Terangkut

Pada umumnya pemilihan antara mempertimbangkan berat dan volume tidak bisa berjalan bersama. Pada penelitian ini, penggunaan berat terpilih menjadi alternatif yang digunakan sehingga timbul broken stowage atau ruang sisa yang tidak dapat digunakan lagi karena load factor berat $\geq 100 \%$. Timbulnya broken stowage mengakibatkan opportunity cost berupa pendapatan yang hilang dikarenakan telah memilih alternatif penggunaan load factor berat.

Tabel 6. Opportunity cost

\begin{tabular}{cccc}
\hline Skenario & $\begin{array}{c}\text { Broken stowage } \\
(\% / B o x)\end{array}$ & $\begin{array}{c}\text { Opportunity cost } \\
\text { (Jt-Rp./Box) }\end{array}$ & $\begin{array}{c}\text { Total Opportunity cost } \\
\text { (Jt-Rp.) }\end{array}$ \\
\hline Kemasan saat ini & $34 \%$ & 359,06 & $2.154,36$ \\
1 & $7 \%$ & 53,18 & 324,16 \\
2 & $11 \%$ & 76,92 & 519,34 \\
3 & $16 \%$ & 109,52 & 780,99 \\
4 & $41 \%$ & 344,33 & $2.880,99$ \\
\hline
\end{tabular}

\section{e. Perbandingan Biaya}

Perbandingan biaya total yang digunakan untuk perbandingan biaya logistik adalah biaya bahan baku, biaya penyimpanan, biaya konsolidasi, biaya pengepakan, biaya pengiriman dengan moda transportasi darat maupun transportasi laut, dan biaya tambahan untuk penggunaan penerapan atau dunnage. Dari skenario 1 hingga skenario 4, penggunaan skenario 2 yaitu kombinasi inovasi kemasan sekunder 1 dengan kemasan ekspor saat ini adalah skenario dengan biaya logistik satuan yang rendah sebesar Rp. 21.439.940/ton. Namun, penggunaan skenario 2 tidak lebih murah daripada kemasan saat ini.

Perhitungan keuntungan dilakukan dengan biaya total dari 1 tahun. Perhitungan ini dilakukan dalam 1 tahun karena penggunaan tiap kemasan memiliki maksimal ketahanan pakai yang berbeda beda dengan frekuensi pengiriman yang sama. Sehingga tiap skenario memiliki biaya pengepakan yang berbeda - beda. Skenario 2 adalah skenario memiliki keuntungan paling banyak daripada kemasan saat ini dan skenario yang lain yaitu sebesar Rp. 8.364.996/ton dalam setahun. 


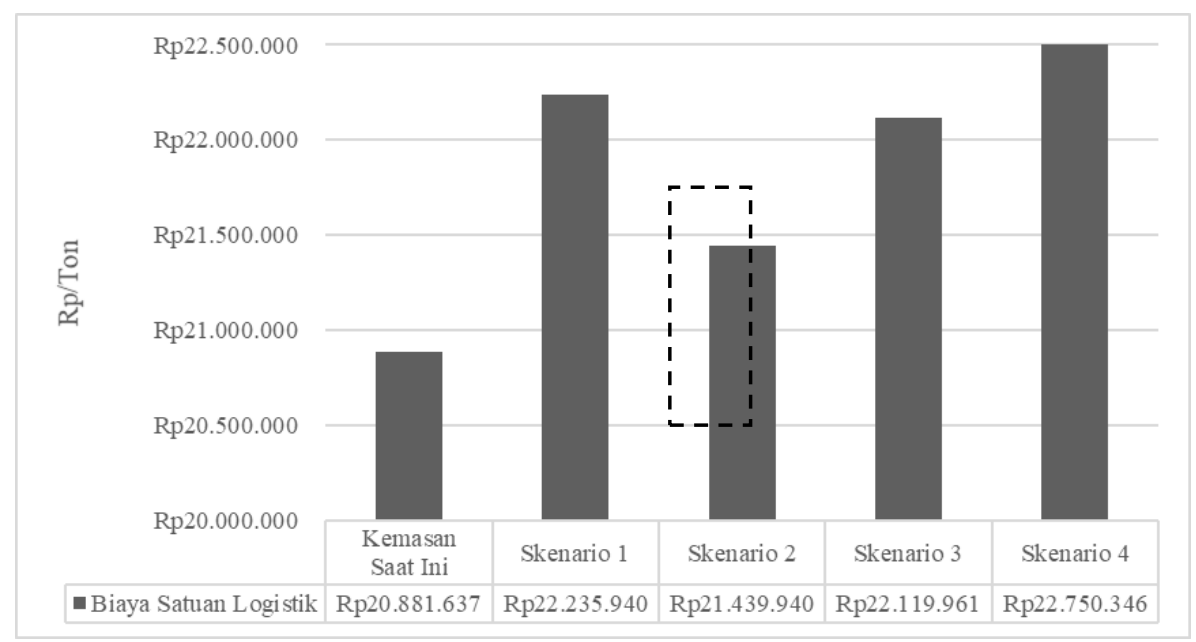

Gambar 14. Perbandingan Biaya Satuan Logistik

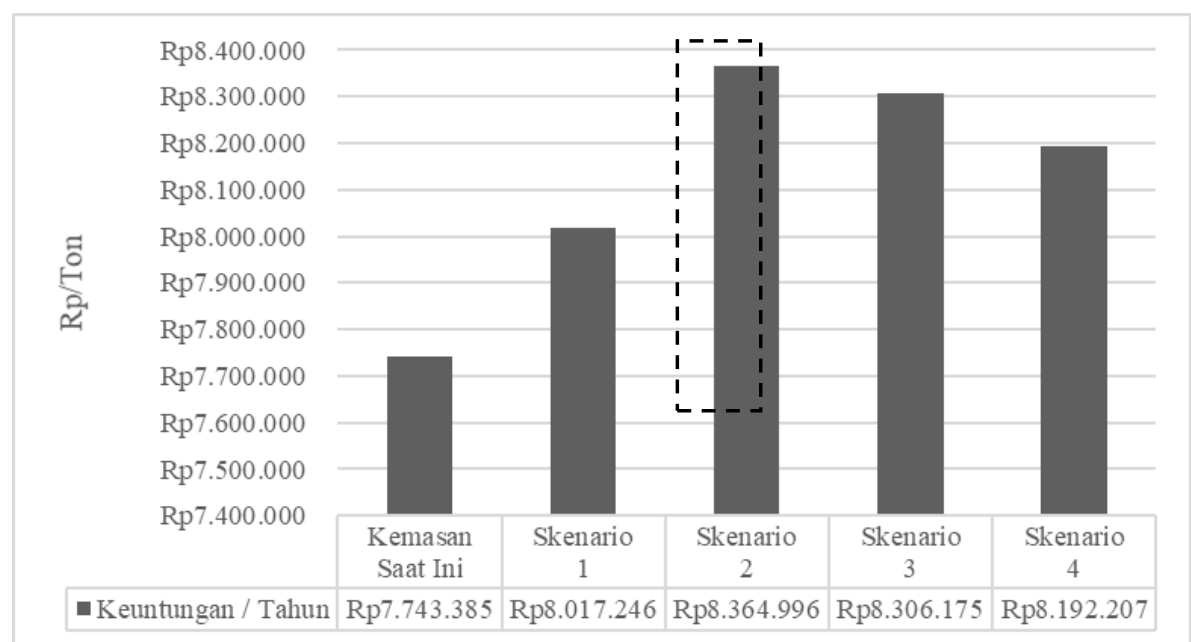

Gambar 15. Perbandingan Keuntungan (Tahun)

Broken stowage atau ruang sisa yang tidak dapat digunakan menimbulkan adanya kerusakan ketika muatan dikirim dengan menggunakan moda transportasi. Solusi yang ditawarkan untuk mencegah kerusakan karena adanya broken stowage atau ruang sisa yang tidak dpat digunakan mencapai $>10 \%$ adalah penggunaan dunnage atau penerapan. Semakin besar broken stowage atau ruang sisa yang tidak bisa digunakan, maka semakin banyak juga penerapan atau dunnage yang dibutuhkan.

Tabel 7. Biaya Dunnage pada Truk CDD Reefer

\begin{tabular}{cccc}
\hline \multirow{2}{*}{ Skenario } & \multirow{2}{*}{$\begin{array}{c}\text { Broken } \\
\text { stowage }\end{array}$} & \multicolumn{2}{c}{ Biaya Dunnage } \\
\cline { 3 - 4 } & $12 \%$ & Rp./moda & Rp./ton \\
\hline 1 & $13 \%$ & 677.825 & 64.116 \\
2 & $13 \%$ & 677.813 & 67.243 \\
3 & $23 \%$ & 779.400 & 72.167 \\
4 & & &
\end{tabular}


Tabel 8. Biaya Dunnage pada Reefer Container $40 \mathrm{ft}$

\begin{tabular}{cccc}
\hline \multirow{2}{*}{ Skenario } & Broken & \multicolumn{2}{c}{ Biaya Dunnage } \\
\cline { 3 - 4 } & stowage & Rp./moda & Rp./ton \\
\hline 1 & - & - & - \\
2 & $11 \%$ & 977.850 & 44.016 \\
3 & $16 \%$ & 977.850 & 46.488 \\
4 & $41 \%$ & 4.818 .825 & 268.790 \\
\hline
\end{tabular}

\section{f. Perbandingan Waktu}

Perhitungan waktu total yang digunakan dalam perbandingan waktu tiap kegiatan untuk muatan ekspor adalah pengiriman muatan, penyimpanan muatan dan penanganan muatan. Dari skenario 1 hingga skenario 4 didapatkan hasil waktu yang paling rendah adalah skenario 4 dengan penggunaan inovasi kemasan sekunder 2. Waktu penanganan muatan dibedakan dari pengunaan alat bongkar muat dan jumlah Tenaga Kerja Bongkar Muat (TKBM).

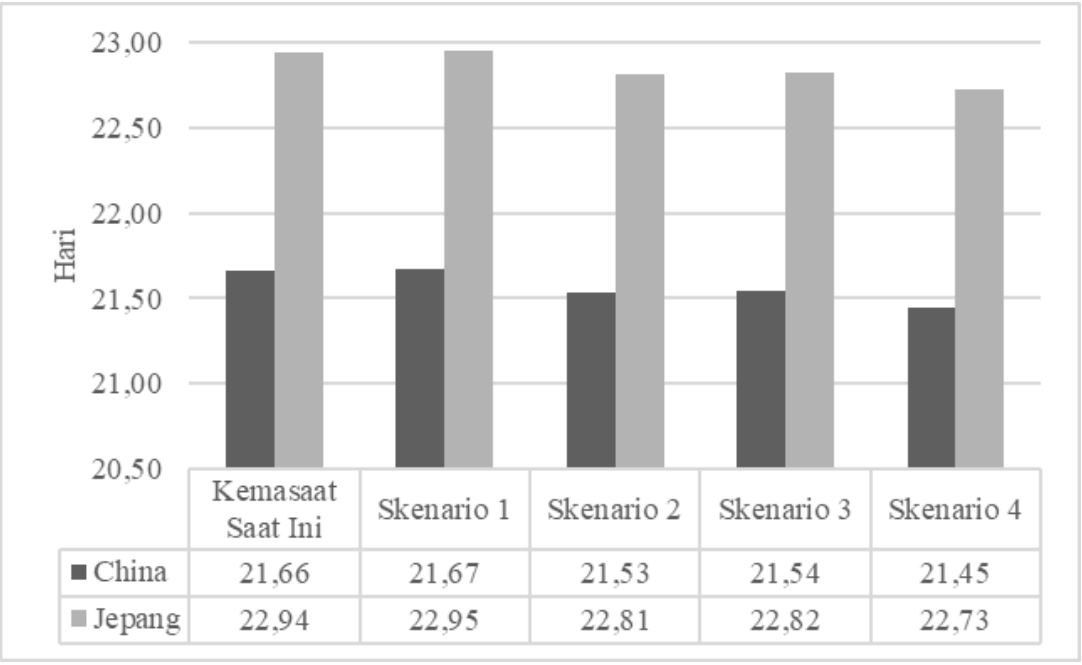

Gambar 16. Perbandingan WaktuTotal

\section{g. Analisis Kekuatan / Buckling}

Dengan menggunakan formula (8) untuk perhitungan buckling diperoleh beban maksimum untuk masing-masing skenario sebagai berikut:

Tabel 9. Hasil Perhitungan Beban Maksimum tiap Skenario

\begin{tabular}{ccccc}
\hline \multirow{2}{*}{ Skenario } & $\begin{array}{c}\text { Beban Merata } \\
(\mathbf{k N})\end{array}$ & \multicolumn{2}{c}{ Beban Maksimum } & \begin{tabular}{c} 
Maks. \\
\cline { 3 - 4 }
\end{tabular} \\
\cline { 3 - 4 } & 0,00288 & $(\mathbf{k N})$ & $\mathbf{( k g )}$ & Tumpukan \\
\hline 2 & 2,02 & 23,23 & $2.322,71$ & 3 \\
3 & 2,02 & 23,23 & $2.322,71$ & 3 \\
4 & 0,23 & 5,42 & 542,14 & 4 \\
\hline
\end{tabular}

Beban merata menunjukkan besaran beban pada tiap tiang $(\mathrm{kN})$, dimana skenario 2 dan 3 memiliki besaran beban yang sama yaitu 2,02 kN dengan maksimum tumpukan 3 (tiga) kemasan.

\section{h. Model Standardisasi Kemasan menurut Berat}

Inovasi kemasan yang dirancang dapat digunakan untuk pengiriman muatan lainnya dengan kebutuhan suhu rendah dengan moda transportasi darat dan moda transportasi laut khusunya dengan reefer container $40 \mathrm{ft}$.

Model standardisasi kemasan menurut berat mempertimbangkan jumlah permintaan (ton) dan berat muatan tiap kemasan $(\mathrm{kg})$. Model ini dibuat untuk mengetahui jumlah kemasan (unit), berat total ( $\mathrm{kg}$ ), 
kebutuhan moda transportasi (unit), volume $\left(\mathrm{m}^{3}\right)$, berat tiap moda transportasi (ton), load factor berat, load factor volume, broken stowage, loss revenue berat, dan biaya logistik yang harus dikeluarkan.

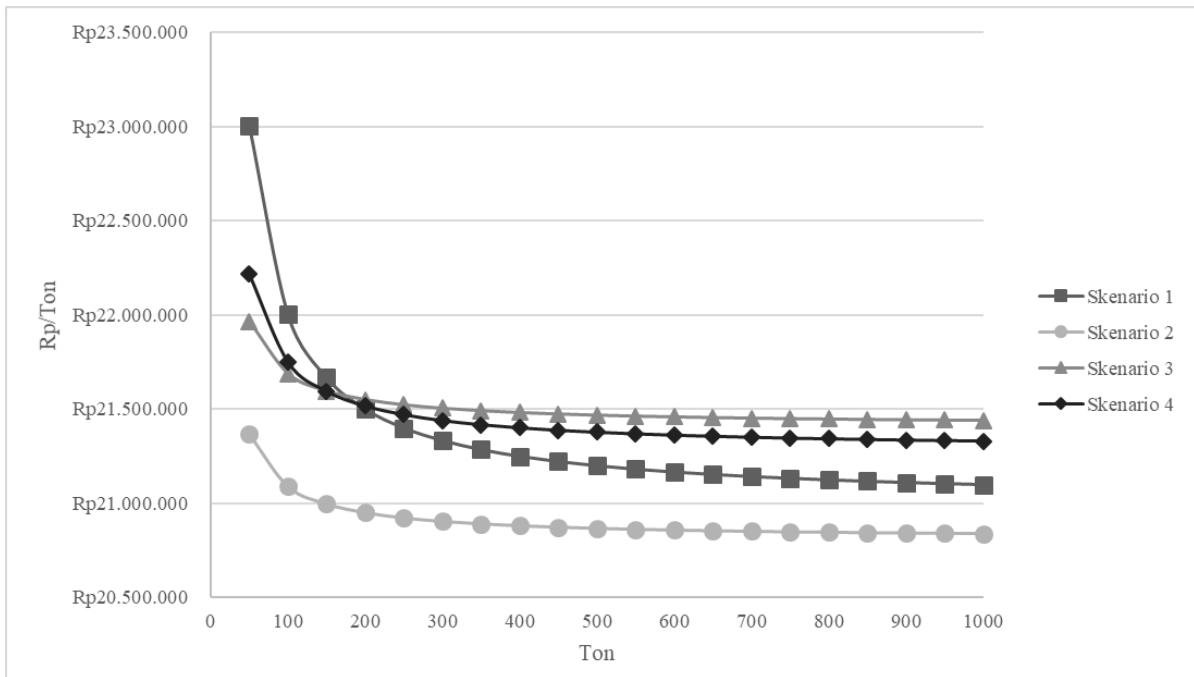

Gambar 27. Analisis Sensitivitas Permintaan terhadap Biaya Satuan dengan Reefer Container $40 \mathrm{ft}$

Analisis sensitivitas digunakan untuk mengetahui skenario mana yang akan digunakan jika terjadi perubahan pada besaran jumlah permintaan (ton). Hasil analisis menunjukkan semakin besar jumlah permintaan dalam satuan ton per tahun, semakin rendah biaya logistik satuan (Rp./ton) yang dihasilkan.

\section{i. Model Standardisasi Kemasan Menurut Volume}

Model standardisasi kemasan menurut volume ditinjau menurut pertimbangan load factor volume yang digunakan untuk memastikan model standardisasi kemasan menurut berat (ton) akurat atau tidak. Model standardisasi kemasan volume mempertimbangkan volume $\left(\mathrm{m}^{3}\right)$, jumlah kemasan (unit), berat tiap moda transportasi (ton), broken stowage dan load factor berat. Hasil analisis menunjukkan semakin besar volume muatan, semakin rendah biaya logistik satuan (Rp./ton).

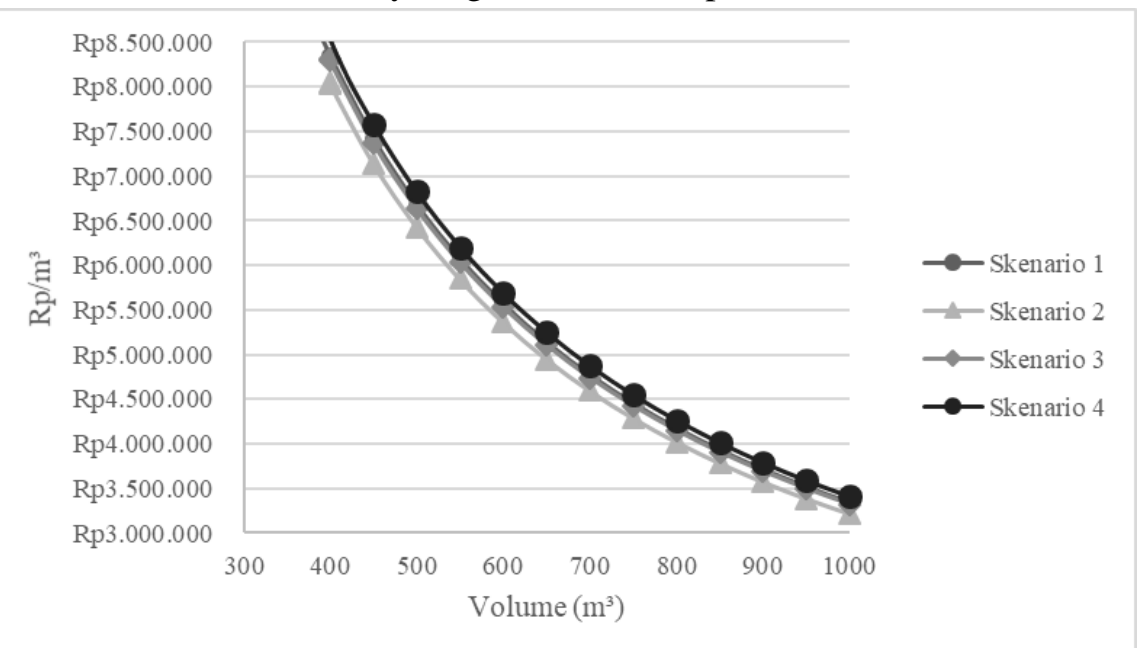

Gambar 38. Analisis Sensitivitas Volume $\left(\mathrm{m}^{3}\right)$ terhadap Biaya Satuan $\mathrm{Rp} / \mathrm{m}^{3}$

\section{Kesimpulan}

Dengan penggunaan kemasan ekspor oleh Usaha Kecil dan Menengah (UKM) saat ini banyak ruang sisa yang tidak dipergunakan (broken stowage), sehingga tercipta ide inovasi kemasan yang dapat mengurangi ruang sisa tersebut dan mengurangi opportunity cost akibat adanya potensi kehilangan pendapatan. Selain itu, beberapa inovasi kemasan ini memenuhi standar pengiriman rantai dingin. Berdasarkan perbandingan kapasitas kemasan terhadap moda transportasi darat dan moda transportasi 
laut, skenario 1 adalah skenario yang memiliki kapasitas terbanyak yaitu 1.139 kemasan untuk moda transportasi darat dan 2.340 untuk moda transportasi laut dengan reefer container $40 \mathrm{ft}$. Menurut perbandingan biaya satuan logistik, skenario 2 menghasilkan biaya logistik satuan yang rendah sebesar Rp. 21.439.940/ton dengan total keuntungan 8.364.996/ton. Sedangkan, skenario 4 membutuhkan waktu paling sedikit yaitu sebesar 21,39 hari untuk waktu total ke China dan 22,67 hari untuk pengiriman ke Jepang. Perbedaan total waktu ini diakibatkan oleh waktu penanganan muatan di UKM dan waktu penanganan muatan di konsolidasi. Inovasi kemasan pada penelitian ini dapat digunakan untuk muatan beku lain selain muatan beku produk olahan ikan. Begitu juga dengan model standardisasi ini dapat digunakan untuk produk lain sesuai dengan jumlah permintaan dan jumlah berat tiap kemasan sehingga didapatkan output sebagai berikut: (a) load factor berat, (b) load factor volume, (c) total biaya logistik, (d) biaya satuan logistik dan (e) berat dan pendapatan yang hilang akibat tidak memaksimalkan kapasitas ruang pada moda transportasi yang digunakan.

\section{Daftar Pustaka}

Arduiona, G. (2010). Cold Chain in the Shippung Industry: Bulk Versus Container in the Banana Trade: Italy.

Badan Pusat Statistik. (2017). Produksi Perikanan Tangkap Menurut Jenis Ikan di Kabupaten Lamongan, 2017 : Badan Pusat Statistika.

Bianca, L. (2016). Sistem Rantai Dingin (Cold Chain) dalam Implentasi Sistem Logistik Ikan

Nasional (SLIN): Supply Chain Indonesia [online] Juli 2016. https://supplychainindonesia.com/ sistem-rantai-dingin-cold-chain-dalam-implementasi-sistem-logistik-ikan-nasional-slin.html

(Diakses 12 Oktober 2019)

Christopher, M. (1998). Logistics and Supply Chain Management. London: Prentice Hall.

Codex Alimentarius Commission. (2009). Code Practice for Fish and Fishery Product First Edition. Rome: FAO/WHO Food Standards Programme.

International Trade Center. (2018). Bilateral Trade between Indonesia China 2018 : International Trade Center.

Izza, F. F. (2017). Desain Konseptual Kemasan Muatan Pelayaran Rakyar : Studi Kasus Pelayaran Rakyat Kalimas Surabaya : Surabaya : ITS.

Johar, S. A. (2019). Studi Pengembangan Kemasan Untuk Angkutan Laut Wilayah Kepulauan: ITS. Surabaya : ITS.

Kementerian Kelautan dan Perikanan. (2019). Kementerian Kelautan dan Perikanan. Jakarta.

Rusthon, A. (2010). Logistics and Distribution Management, 4th ed. London: Kogan Page.

Simatupang, T. M. (2016). Struktur dan Sistem Rantai Pendingin Ikan dalam Rangka Pengembangan Sistem Logistik Ikan Nasional (SLIN) [online] Juli 2016. https://supplychainindonesia.com/sistemrantai-dingin-cold-chain-dalam-implementasi-sistem-logistik-ikan-nasional-slin.html (Diakses 12 Oktober 2019)

Sondoro, Y. (2016). Pengawetan Ikan dengan Menggunakan Metode Pembekuan (Cold Storage).[online] Juli 2016. http://yunias19ocean.blogspot.co.id/2011/05/ pengawetan-ikandengan-menggunakan.html (Diakses pada 12 Oktober 2019.

Suyono, R.P. (2010). SHIPPING Pengangkutan Intermodal Ekspor Impor Melalui Laut - Edisi Keempat. Jakarta: PPM Manajemen.

Tambunan, T. T. H. (2009). UMKM di Indonesia. Bogor: Ghalia Indonesia.

Zaroni. (2017). Biaya Logistik Agregat. Supply Chain Indonesia. [online] April 2017. https://supplychainindonesia.com/biaya-logistik-agregat/html. (Diakses pada 12 Oktober 2019). 